\title{
Ksiq̨żki obrazkowe a projekty internetowe - podobieństwa w strategiach wizualnych stosowanych przez polskich twórców dla dzieci
}

STRESZCZENiE: Artykuł, na podstawie wybranych przykładów, wskazuje na paralelność tworzonych w Polsce projektów graficznych adresowanych do najmłodszego odbiorcy, a publikowanych zarówno w papierowych książkach kodeksowych, jak i cyfrowych projektach internetowych. Wizualna „sztuka internetu” inspiruje się tradycyjną książką, a najnowsze picturebooki - internetem i grami komputerowymi. W efekcie podobieństwa obrazkowych opowieści i przekazów edukacyjnych dla dzieci w starych i nowych mediach, często autorstwa tych samych twórców, wskazują na mediamorfozę i transgresję mediów, co pozwala na płynne przejścia pomiędzy nimi, przy jednoczesnym rozwianiu niektórych obaw związanych z uczestniczeniem dziecka w kulturze cyfrowej.

SŁoWA KLUCzowE: strategie wizualne, twórczość dla dzieci, picturebook, nowe media, projekty internetowe, grafika dla dzieci, książka obrazkowa.

* Uczestniczka studiów doktoranckich z zakresu komunikacji społecznej i mediów, prowadzonych na Wydziale Dziennikarstwa, Informacji i Bibliologii Uniwersytetu Warszawskiego. 
Widzenie poprzedza słowa. Dziecko patrzy i rozpoznaje, zanim nauczy się mówić1.

John Berger, Sposoby widzenia

$\bigvee_{\text {szereg badań związanych z abordażem tzw. starych i nowych }}^{\text {ostatnich latach prowadzonych jest wiele obserwaci i powstaje }}$ mediów. Książkom drukowanym przeciwstawia się elektroniczne, papierowy nośnik informacji i literatury analizowany jest jako odrębny i niezależny byt w komunikacji bibliologicznej, plik cyfrowy - już niekoniecznie ${ }^{2}$. Naukowcy, zwłaszcza pedagodzy, psycholodzy i socjolodzy, w związku z przekonaniem graniczącym z pewnością, iż z obcowania z książką papierową, w tym obrazkową ${ }^{3}$, płyną wyłącznie korzyści, a w relacjach dziecka z mediami elektronicznymi najczęściej widzą zagrożenia ${ }^{4}$, podkreślają odrębność, wręcz dwubiegunowość adresowanych do

${ }^{1}$ Cyt. z fragmentu wprowadzenia od autora wydrukowanego na okładce, J. Berger, Sposoby widzenia, Aletheia, Warszawa 2020.

2 „Komunikacja bibliologiczna, która jest rodzajem komunikacji społecznej, rozumiana jest jako proces wprowadzania książki do obiegu społecznego”, także „Komunikacja bibliologiczna per se jawi się jako system (makrosystem). Pewne podmioty biorące w niej udział są z kolei swoistymi mikrosystemami, np. biblioteki i księgarnie. (...) Pomiędzy podmiotami, biorącymi udział w komunikacji, powstaje swoista sieć zależności (relacji), w której dochodzi/może dochodzić do interakcji. Tak ujawnia się sieciowy charakter komunikacji bibliologicznej" cyt. za: S. D. Kotuła, Komunikacja bibliologiczna wobec World Wide Web, Warszawa 2012, s. 114, 120; diagram ukazujący pozycję książki elektronicznej w komunikacji bibliologicznej, określanej przez S. Kotułę jako e-książka - tamże, s. 150.

${ }^{3}$ Książka obrazkowa (ang. picturebook) „to taka postać książki dla dziecka, w której podstawowym elementem wypowiedzi jest obraz, gdzie strona wizualna, jeśli nie stanowi celu głównego, wiąże się z tekstem na zasadach równouprawnienia. (...) Liczne opracowania naukowe poświęcone książce obrazkowej, a także liczne przykłady tego gatunku, każą ją traktować jako artefakt kulturowy, w którym obrazy i słowa są drukowane na papierze i ograniczone oprawą (okładkami). Podkreśla się przy tym właściwie nieograniczone możliwości współczesnego edytorstwa i poligrafii, bardzo chętnie stosowane w produkcji książek obrazkowych, dzięki którym gatunek ten kwitnie jako forma sztuki" za: M. Cackowska, Ksiq̨żka obrazkowa, [w:] Encyklopedia dzieciństwa, red. D.Waloszek [online] Zielona Góra 2015. [dostęp 1 września 2020]. Dostępny w World Wide Web: http://encyklopediadziecinstwa.pl/index.php/Ksi\%C4\%85\%C5\%BCka_obrazkowa.

${ }^{4}$ Przekonanie to wywiedzione jest z badań, wyniki niektórych przytaczane i komentowane są przez badaczy m.in. w artykułach: W. Matras-Mastalerz, Potencjał edukacyjny, socjalizacyjny, wychowawczy i terapeutyczny ksiq̨żki dziecięcej, [w:] Ksiq̨żki w życiu 
najmłodszych lektur kodeksowych i ich wariantów cyfrowych. Celem niniejszego artykułu nie jest jednak wykazanie kolejnych różnic między tymi formami przekazu, a dowiedzenie paralelności kompozycyjno-wizualnej pomiędzy książkami obrazkowymi a niektórymi projektami internetowymi. Spośród metod badawczych zastosowane tu zostały: analiza porównawcza, study cases oraz indukcja. Jako exemplum posłużą wybrane prace - zarówno książkowe, jak i stricte cyfrowe kilku wybitnych polskich grafików tworzących dla dzieci: Jana Bajtlika, Edgara Bąka, Marty Ignerskiej, Grażyny Lange oraz małżeństwa Aleksandry i Daniela Mizielińskich. Scharakteryzowane zostaną migawkowo, jedynie dla zobrazowania tematu (o twórczości każdego z wymienionych można by stworzyć monografię). Wcześniej przedstawione będą krótko, celem ukazania wielkości zjawiska, wybrane dane z niektórych badań i statystyk przeprowadzonych w kontekście używania przez najmłodszych mediów elektronicznych i kupowania przez ich rodziców tradycyjnych książek papierowych projektowanych dla dzieci. Poprzez sformułowania najmłodsi, dzieci, rozumiani będą tu użytkownicy do 12 roku życia, przy założeniu, że osoby starsze, nastoletnie, to już młodzież. W artykule termin książka obrazkowa będzie stosowany zamiennie z jego odpowiednikiem w języku angielskim - picturebook.

\section{Ze smartfonem od urodzenia}

Badania dotyczące skutków obcowania dzieci z mediami cyfrowymi nie nastrajają optymistycznie. 0 ich wynikach informuje w Polsce m.in. Fundacja Dajemy Dzieciom Siłę (kiedyś pod nazwą Fundacja Dzieci Niczyje)"

najmłodszych, red. M. Antczak, A. Walczak-Niewiadomska, Łódź 2015, s. 105-120; E. Kruszyńska, Książka obrazkowa i jej rola w rozwoju dzieci - wprowadzenie w problematykę, „Warmińsko-Mazurski Kwartalnik Naukowy. Nauki Społeczne” 2012, nr 3, s. 183-190; M. Cackowska, Co ma książka obrazkowa do interaktywnej aplikacji książkowej?, „Ryms” 2013, nr 20, s. 2-4; A. Jegier, Media w wychowaniu dzieci - korzyści i zagrożenia, [w:] Wychowanie i wspieranie rozwoju małych dzieci w domu, żłobku i przedszkolu, red. A. Mikler-Chwastek, Warszawa 2017, s. 182-195.

5 A. Gierczak-Cywińska, Ogranicz ekrany, zadbaj o mózg swojego dziecka, [w:] Polityka.pl [online] [dostęp 2 września 2020]. Dostępny w World Wide Web: http://ogranicz-ekrany-zadbaj-o-mozg-swojego-dziecka.read. 
a na świecie np. Jean M. Twenge, zaangażowana od ponad 25 lat w badania dotyczące różnic generacyjnych ${ }^{6}$.

Badania ilościowe Korzystanie z urządzeń mobilnych przez małe dzieci w Polsce zrealizowane przez Fundację Dzieci Niczyje w 2015 r. na ogólnopolskiej próbie reprezentatywnej dla dzieci w wieku 6 miesięcy 6,5 lat, wykazały, że korzystanie przez maluchy z mobilnych urządzeń elektronicznych jest powszechne. Najistotniejsze konkluzje z badania: aż 64 proc. dzieci w wieku od 6 miesięcy do 6,5 lat korzysta z urządzeń mobilnych, i aż $25 \%$ z nich - codziennie. $26 \%$ dzieci posiada własne urządzenie mobilne, $79 \%$ dzieci ogląda na nich filmy, a $62 \%$ gra w gry. Około $63 \%$ najmłodszych dzieci zdarzyło się bawić smartfonem lub tabletem bez konkretnego celu, i aż 69\% rodziców udostępnia dzieciom urządzenia mobilne, kiedy muszą zająć się własnymi sprawami, z czego 49\% rodziców udostępnianie dziecku urządzeń elektronicznych z mediami cyfrowymi traktuje jako rodzaj nagrody ${ }^{7}$.

Amerykańska psycholog i socjolog Jean Twenge wprowadziła pojęcie iGen - określenie generacji dzieci urodzonych po 2007 r. (to rok, w którym na rynek wszedł pierwszy iPhone). Wyrażenie to w swoim semiotycznym znaczeniu parafrazuje nazwy popularnych na rynku produktów firmy Apple, takich jak iPhone, iPad czy iPod. Nazwy te miały i mają wskazywać na fakt, iż urządzenia te mogą być w stałym i ciągłym powiązaniu z internetem (internet - skrót od ang. słów „inter-network”, dosłownie „między-sieć” - ogólnoświatowy system połączeń między komputerami, „Sieć sieci”). Sugeruje to litera „"” dodana przed nazwą urządzenia. Podobne skojarzenia ma wywoływać nazwa iGen - skrót od iGeneracji ${ }^{8}$. Według badaczki, to pokolenie internetu to dzieci, które nie znają świata

${ }^{6}$ Fenomen badań J. Twenge szerzej opisany w: M. Janusz-Lorkowska, iGen jako użytkownik informacji w kontekście kategorii generacji - próba ujęcia na podstawie ksiq̨żki Jean M. Twenge „iGen”, „Toruńskie Studia Bibliologiczne” 2019, nr 2 (23) 2019, s. 139-158 [online] [dostęp 2 września 2020]. Dostępny w World Wide Web: https://apcz.umk.pl/ czasopisma/index.php/TSB/article/viewFile/TSB.2019.018/25309.

7 A. Bąk, Korzystanie z urządzeń mobilnych przez małe dzieci w Polsce. Wyniki badania ilościowego. Raport Fundacji Dzieci Niczyje, Warszawa 2015, s. 4 [online] [dostęp 2 września 2020]. Dostępny w World Wide Web: https://fdds.pl/wp-content/uploads/2016/05/ Bak_Korzystanie_z_urzadzen_mobilnych_raport.pdf.

${ }^{8}$ J. M. Twenge, iGen. Dlaczego dzieciaki dorastajace w sieci sa mniej zbuntowane, bardziej tolerancyjne, mniej szczęśliwe - i zupełnie nieprzygotowane do dorosłości. I co to oznacza dla nas wszystkich, tł. O. Dziedzic, Sopot 2019, s. 10. 
bez telefonów komórkowych, którym od urodzenia towarzyszą smartfon i tablet. Twenge wykazała, że bycie on-line wśród amerykańskich dzieci i nastolatków systematycznie rośnie z roku na rok, odkąd rozpowszechnił się internet, ale po roku 2007 - kiedy wprowadzono smartfony, skok był gwałtowny - ich liczba natychmiast podwoiła się?.

Badania Fundacji Dajemy Dzieciom Siłę dotyczące polskich użytkowników mediów cyfrowych potwierdzają wcześniejsze wyniki ${ }^{10}$ - coraz więcej bardzo małych dzieci korzysta z tabletów lub smartfonów. W grupie najmłodszych - rocznych i dwuletnich (!) jest ich już ponad 40\%, z czego około 13\% codziennie. W swoich raportach Fundacja cytuje naukowców, którzy zwiastują tzw. cyfrową demencję ${ }^{11}$. Z badań m.in. prof. Dimitria A. Christakisa, dotyczących rozwoju mózgu, wynika, że zbyt długa ekspozycja na ekrany do trzeciego roku życia wywołuje poważne zaburzenia uwagi, problemy z koncentracją, z kontrolą emocji, częściej u takich dzieci diagnozowane jest ADHD, mają też gorsze wyniki w nauce. Przyczyną mogą być zaburzenia w rozwoju układu limbicznego i kontroli nad ciałem migdałowatym ${ }^{12}$. Cytowana wyżej Twenge, w konkluzjach ze swoich badań zwraca uwagę, że w sytuacji powszechnego i masowego korzystania przez najmłodszych z urządzeń cyfrowych, należy zmienić podejście do projektowania podręczników i innych pomocy naukowych dla nich. Proponuje, by wychodzić naprzeciw oczekiwaniom najmłodszych i podczas ich kształcenia jak najczęściej wykorzystywać media cyfrowe, wiele treści edukacyjnych przenosić do internetu, a przekaz w tradycyjnych książkach urozmaicać nie tylko graficznie, ale także multimedialnie, poprzez odsyłanie do filmów, podcastów czy nawet gier komputerowych ${ }^{13}$, a więc wykorzystywanie konwergencyjności mediów, mediamorfozy, czyli de facto tworzenia książek hybrydowych ${ }^{14}$.

9 Tamże, s. 11, 60.

10 A. Gierczak-Cywińska, dz. cyt.

11 Pierwsze prace na ten temat pojawiły się dużo wcześniej, zob. np. M. Spitzer, Cyfrowa demencja, Słupsk 2012.

${ }^{12}$ Inne badania na ten temat, np. N. Kardaras, Dzieci ekranu. Jak uzależnienie od ekranu przejmuje kontrolę nad naszymi dziećmi i jak wyrwać je z transu, Warszawa 2018; A. Alter, Uzależnienia 2.0. Dlaczego tak trudno się oprzeć nowym technologiom, Kraków 2018.

13 J. M. Twenge, dz. cyt., s. 325-353.

14 Pojęcie konwergencji, patrz: H. Jenkins: Kultura konwergencji. Zderzenie starych i nowych mediów, Warszawa 2006; Mediamorfoza zob. T. Goban-Klas, Społeczeństwo 


\section{Potęga lilipucich wydawnictw}

Jednocześnie warto zderzyć dane świadczące o masowości korzystania z mediów cyfrowych przez najmłodszych z corocznymi raportami polskiej Biblioteki Narodowej Ruch Wydawniczy w Liczbach. Wynika z nich jednoznacznie, że udział książki dziecięcej (tradycyjnej, papierowej) w rynku książki w Polsce od lat 90. wzrósł ponad pięciokrotnie (!) i ciągle rośnie. Obecnie wynosi 33\% (w tym dla najmłodszych - 28\%, dla młodzieży 5\%). W najnowszym raporcie (za rok 2019) można przeczytać, że znowu najbardziej zwiększyła się oferta książek obrazkowych (picturebooków), dedykowanych dzieciom w wieku 0-5 lat. W 2019 r. nowych tytułów w tej kategorii wydano o 455 więcej niż rok wcześniej ${ }^{15}$. Przybywa też wydawnictw mających w swojej ofercie tylko książki dla dzieci, w tym wydawnictw tzw. lilipucich ${ }^{16}$, specjalizujących się w projektach ambitnych i wysmakowanych estetycznie, stawiających wysoko poprzeczkę w jakości książek adresowanych do dzieci. Przed dekadą było ich kilka, obecnie jest ich kilkadziesiąt ${ }^{17}$. Przykłady wydawnictw lilipucich to Dwie Siostry, Wytwórnia, Muchomor, Hokus-Pokus, Format, Ezop, Zakamarki, Bajka, Tatarak, Czerwony Konik, EneDueRabe, Babaryba, Entliczek, Tako, Widnokrąg i in. Zdobywają nagrody i wyróżnienia, w tym jedną z najważniejszych nagród w kategoriach projektowania i estetyki książki - Bologna Ragazzi Award ${ }^{18}$, przyznawaną podczas Targów Książki dla Dzieci w Bo-

medialne, Warszawa 2005; pojęcie książka hybrydowa: A. Bożek, L. Kamińska-Mazur, Książka hybrydowa - kod QR sposobem na koegzystencję książki drukowanej z e-bookiem [online], „Biuletyn EBIB” 2012, nr 7 (134) [dostęp 15 października 2020]. Dostępny w World Wide Web: http://ebibojs.pl/index.php/ebib/article/view/513.

${ }^{15}$ Ruch Wydawniczy w Liczbach, t. 69, oprac. O. Dawidowicz-Chymkowska, Warszawa 2020, s. 39.

16 Wydawnictwa lilipucie - pojęcie spopularyzowane przez pisarkę i dziennikarkę Joannę Olech na łamach „Tygodnika Powszechnego”, gdzie recenzuje picturebooki. Obecnie podchwycone przez badaczy. Odnosi się do małych, niezależnych oficyn, powstałych w odpowiedzi na potrzeby rynku po roku 2000, publikujących książki obrazkowe o wysokim poziomie artystycznym, literackim i edytorskim.

17 E. Jamróz-Stolarska, K. Biernacka-Licznar, N. Paprocka, Lilipucia rewolucja: awangardowe wydawnictwa dla dzieci i młodzieży w Polsce w latach 2000-2015. Produkcja wydawnicza, bibliografia, Warszawa 2018.

18 Międzynarodowa nagroda przyznawana rokrocznie od roku 1966, podczas targów książki Bologna Children's Book Fair w Bolonii, za najciekawszą na świecie, pod względem 
lonii (od wielu lat rokrocznie w finale są Polacy). Fakt, iż takich wydawnictw przybywa oraz w zasadzie tylko w tym segmencie rynku książki przychód z wydawanych tytułów rośnie, świadczy o coraz większym popycie na obrazkową książkę dla dzieci. To daje nadzieję na poszerzanie tzw. rodziny czytelniczej, mimo iż nie ma badań mówiących o tym, ile czasu dziennie spędza dziecko przeglądając książkę czy bawiąc się nią np. w towarzystwie rodzica, poza badaniami zleconymi przez fundację „ABC XXI - Cała Polska czyta dzieciom”, na wybranej grupie osób - wśród rodziców deklarujących codzienne czytanie niemowlętom ${ }^{19}$.

\section{Rodzima twórczość dla dzieci w mediach cyfrowych i drukowanych}

Dziś wielu polskich grafików, nagradzanych za twórczość dla dzieci, tworzy zarówno analogowe picturebooki (nakładem wymienionych wyżej wydawnictw lilipucich), jak i gry on-line oraz strony i różne projekty

graficznym i edytorskim, książkę dla dzieci. Obejmuje kategorie: Fiction, Non Fiction, Opera Prima (dla niepublikowanych autorów i ilustratorów) oraz, od roku 2020, Comics. Wiecej na: Bologna Children's Book Fair [online] [dostęp 30 sierpnia 2020]. Dostępny w World Wide Web: http://www.bookfair.bolognafiere.it/en/highlights/awards/bolognaragazziaward/8382.html.

19 To Badanie efektów czytania dzieciom od urodzenia przeprowadzone przez Ośrodek Ewaluacji na zlecenie Fundacji „ABC XXI - Cała Polska czyta dzieciom”. Większość badanych deklarowała czytanie dzieciom ok. 10 min. dziennie. Badanie efektów czytania od urodzenia [online] [dostęp 20 grudnia 2020]. Dostępny w World Wide Web: https://issuu. com/orodekewaluacji/docs/badanie_efekt_w_czytania_od_urodze. Inne badanie wykazuje konieczność uczestniczenia środowiska rodzinnego w przygotowywaniu dzieci do czytania ze zrozumieniem, ale nie podaje czasu, jaki dziecko spędza z rodzicem i książką: M. Jurewicz, Czytanie ze zrozumieniem. Uwarunkowania rodzinne, [online]. Warszawa 2010 [dostęp 20 grudnia 2020]. Dostępny w World Wide Web: http://www.publio.pl/files/ samples/7a/fd/f6/92563/Czytanie_ze_zrozumieniem_Uwarunkowania_rodzinne_demo. pdf; Za granicą natomiast tego typu badania były i są prowadzone dość regularnie, przykładem badania w Hiszpanii: KIDS \& FAMILY READING REPORT: THE RISE OF READ-ALOUD [online] [dostęp 20 grudnia 2020]. Dostępny w World Wide Web: https://www.observatoriodelainfancia.es/ficherosoia/documentos/5719_d_KFRR_The_Rise_of_\%20Read_ Aloud.pdf. Badnia wykazały m.in., że „odsetek rodziców czytających na głos w ciągu pierwszych trzech miesięcy życia dziecka wzrósł o prawie 50\% od 2014 r. do 2016 r. Liczba czytanych na głos książek dzieciom w wieku 6-8 lat do 5-7 dni w tygodniu wzrosła o siedem punktów procentowych". 
internetowe. Wśród nich znalazły się takie nazwiska, jak Jan Bajtlik, Edgar Bąk, Marta Ignerska, Grażka Lange, Aleksandra i Daniel Mizielińscy. Na potrzeby różnych mediów - zarówno „papierowych”, jak i cyfrowych, stosują bardzo podobne strategie wizualne, używają tych samych narzędzi. Wykształceni w kierunku „wizualnego uwodzenia” młodocianego czytelnika, kierują się w projektach cyfrowych tymi samymi zasadami dotyczącymi kompozycji oraz zastosowania barw, a także relacji tekstu i obrazu w kontekście typografii, co w książkach.

Przyjrzyjmy się działalności Jana Bajtlika. Ten młody, polski artysta grafik, mogący pochwalić się międzynarodowymi nagrodami i indywidualnymi wystawami, tworzy plakaty, ilustracje, wzory tkanin, książki, ale też grafikę na potrzeby internetu. Przykłady z jego twórczości, które już prima facie spełniają warunek paralelności, to autorskie książki obrazkowe, takie jak Nić Ariadny, Typogryzmoł i Auto oraz grafika z serii doodle dla polskiej wersji przeglądarki Google LLC z okazji 100-lecia Odzyskania Niepodległości przez Polskę (il. nr 1-4). Bez kontekstu nośnika - a więc obcowania z wymienioną wyżej twórczością autora w konkretnym miejscu - w książce drukowanej lub w internecie, trudno się zorientować, dla którego medium była/jest dedykowana. Widoczne są tu inspiracje tzw. Polską Szkołą Plakatu (zwłaszcza twórczością Lecha Majewskiego), grami - zarówno planszówkami, jak i grami komputerowymi, wykorzystywanie graficznych programów komputerowych dla tworzenia ilustracji i typografii (np. poprzez cyfrowe wypełnianie kolorem obramowań i konturów wybranych elementów ilustracji, ale także przy cyfrowym imitowaniu „ruchów pędzla”, np. w przypadku akwarelowych plam barwnych, jak w Aucie) widoczne jest w każdym z projektów. Zwłaszcza ulubiona przez dzieci gra typu labirynt, eksploatowana swego czasu przez czasopisma dla dzieci, takie jak „Świerszczyk” czy „Miś”, mocno widoczna jest w twórczości Bajtlika. Labiryntowa jest nie tylko opowieść o dawnej Grecji, inspirowana labiryntowym mitem o Minotaurze i Ariadnie w książce Nić Ariadny, ale także rzeka Wisła, symbolizująca rdzeń Polski w przygotowanych dla Google na listopad 2018 r.doodlach. Także litery - w każdym niemal z projektów Bajtlika - grają rolę dosłownie pierwszoplanową - są semiotycznie istotne zarówno dla rozkodowania treści przekazywanej za pomocą pisma, jak i odkodowania sensu ukrytego w ilustracji, ponieważ są jej nieodłączną częścią (patrz np. doodle dla Google, a także Typogryzmoł). 


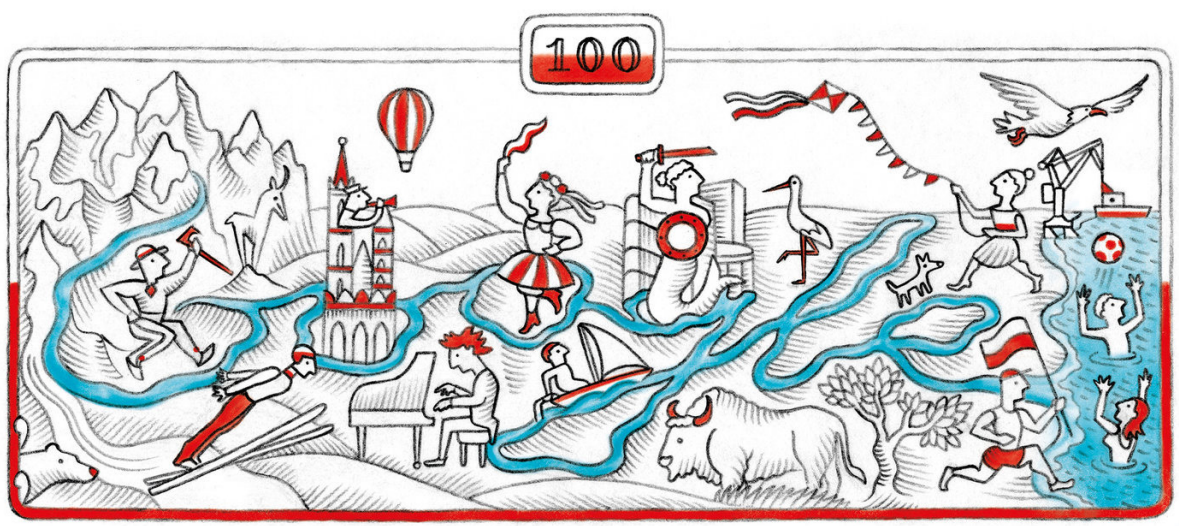

Il. 1. Doodle dla Google w dniu 11 listopada 2018 r.

Źródło: google doodle - jan bajtlik [online] [dostęp 20 grudnia 2020]. Dostępny w World Wide Web: http://jan-bajtlik.squarespace.com/google-doodle

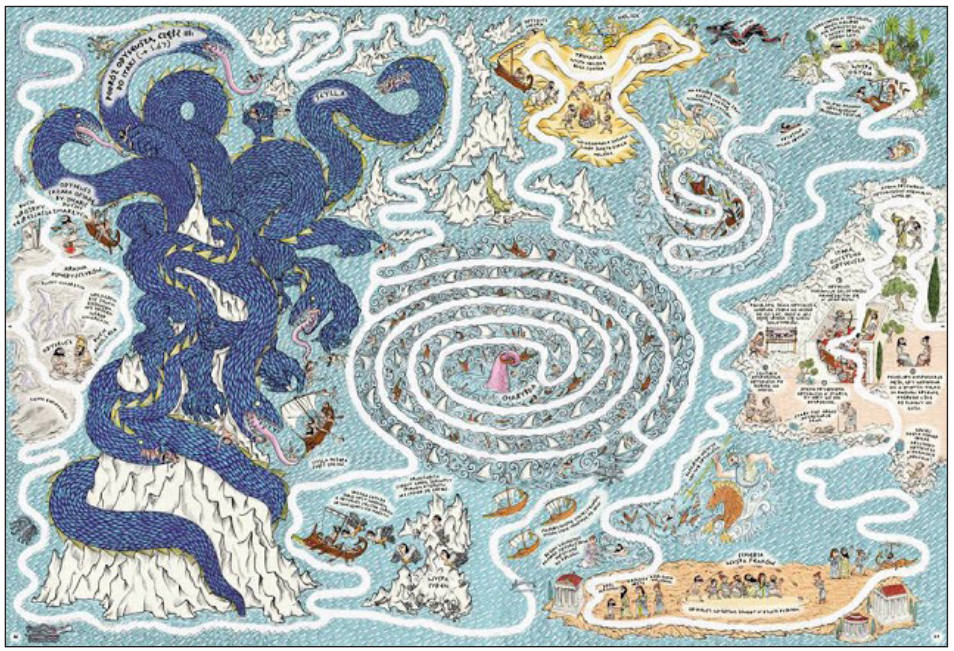

\section{Il. 2. Strona z książki Nić Ariadny}

Źródło: greek myths and mazes - jan bajtlik [online] [dostęp 20 października 2020]. Dostępny w World Wide Web: http://jan-bajtlik.squarespace.com/ariadnes-thread/xui7qmblx6a3vmjg4ljnbz1us1h1ak; także Wydawnictwo Dwie Siostry [online] [dostęp 20 października 2020]. Dostępny w World Wide Web: https:// www.wydawnictwodwiesiostry.pl/katalog/autorzy/prod-nic_ariadny.html 


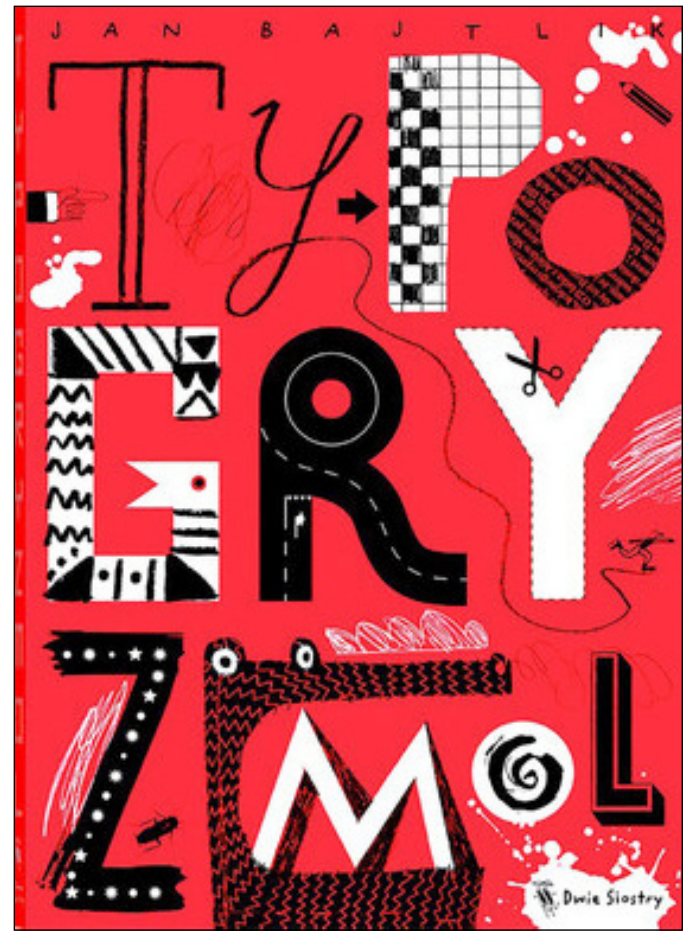

\section{Il.3. Okładka książki}

Typogryzmoł

Źródło: alphadoodler editions jan bajtlik [online] [dostęp 20 grudnia 2020]. Dostępny w World Wide Web: http:// jan-bajtlik.squarespace.com/ alphadoodler-editions

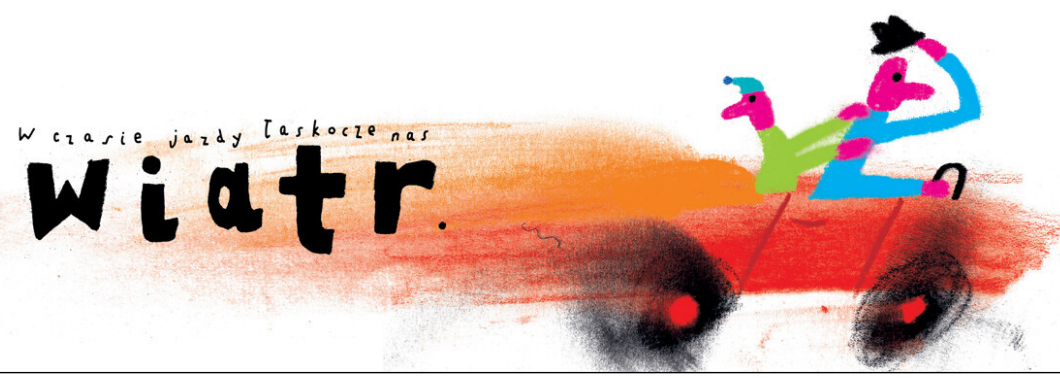

Il. 4. Strona z książki Auto

Źródło: Auto / Jan Bajtlik - Wydawnictwo Dwie Siostry [online] [dostęp 20 grudnia 2020]. Dostępny w World Wide Web: https://www.wydawnictwodwiesiostry.pl/katalog/prod-auto.html 
Podobnie wszechstronnie pracujący jest ilustrator Edgar Bąk. To grafik, tworzący w dużej mierze komputerowo, zajmujący się szeroko pojętą komunikacją wizualną. W projektowaniu skupia się na gramatyce i założeniach projektu, uzyskując efekt końcowy wycyzelowany niczym w równaniu matematycznym. Wrażliwy na sytuacyjny kontekst, lapidarnie cytuje codzienność. Z równym powodzeniem specjalizuje się w wizualnym kreowaniu poważnych podmiotów biznesowych, jak i w ważnych dydaktycznie przekazach adresowanych do dzieci. W pracach, takich jak książki obrazkowe Kto Ty Jesteś?, Mam prawo i nie zawaham się go użyć! czy Egaliterra, ale także w projekcie internetowym promującym interdyscyplinarne działania edukacyjne CNK - Centrum Nauki Kopernik w Warszawie: „50 powodów, dla których na naukę nigdy nie jest za późno" ${ }^{20}$ (il. 5-9), operuje w sposób niemalże identyczny oszczędną, prostą, minimalistyczną formą oraz kontrastową, jaskrawą plamą barwną, co jest według badaczy dziecięcego postrzegania świata, odbijanego w umownej, graficznej rzeczywistości, szczególnie istotne i ważne ${ }^{21}$. Inspiracje strategiami wizualnymi charakterystycznymi dla plakatu - przyciąganie wzroku poprzez jaskrawy kolor, zaskoczenie, poetycki i jednocześnie skondensowany przekaz, hasłowość, umowność bazująca na skojarzeniach i stereotypach, jest w jego ilustracjach książkowych i grafikach tworzonych na strony internetowe tak silna, iż każdy z tych projektów może być de facto plakatem (patrz il. 5), co też wykorzystywali organizatorzy spotkań autorskich lub animatorzy budujący wydarzenia dla dzieci wokół tematów mieszczących się w zagadnieniach książek Edgara Bąka.

${ }^{20}$ Edgar Bąk Studio/Centrum Nauki Kopernik [online] [dostęp 1 września 2020]. Dostępny w World Wide Web: https://edgarbak.info/work/copernicus-science-centre/.

${ }_{21} 0$ roli koloru i kontrastu w grafice/ilustracji adresowanej do dzieci piszą m.in.: A. Teodorczyk, Pomiędzy sztukq̨ a edukacją. Ilustracja w książkach dla dzieci i młodzieży (pod przewodnictwem prof. M. Adamczyka) [dla:] STGU (Stowarzyszenie Twórców Grafiki Użytkowej) [online] [dostęp 2 września 2020]. Dostępny w World Wide Web: https:// www.stgu.pl/stgu_files/Files/Anna_Teodorczyk_Pomi\%C4\%99dzy_sztuk\%C4\%85_a_edukacj\%C4\%85_poprawiona.pdf; także: I. Słońska, Psychologiczne problemy ilustracji dla dzieci, Warszawa 1977. 
[40] 1

\section{Kasuje bilet w autobusie. \\ Jestem patriotkq̨.}

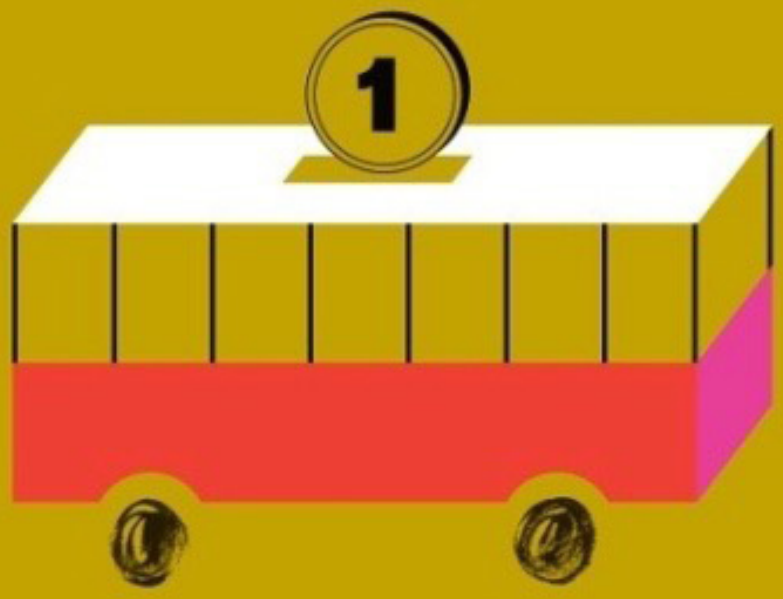

\section{Kto ty jesteś? \\ jestempatriota.pl}

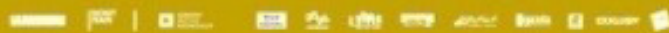

Il. 5. Strona z książki Kto ty jesteś, a jednocześnie plakat zapraszający na wystawę, warsztaty dla dzieci i dyskusję wokół poruszanych w książce tematów Źródło: Jako strona książki - Wydawnictwo Wytwórnia, jako plakat - Owoce i Warzywa, Kto ty jesteś? - Edgar Bąk i Joanna Olech | wystawa w OiWw Warszawie [online] [dostęp 20 grudnia 2020]. Dostępny w World Wide Web: http:// www.owoceiwarzywa.com/kalendarz 


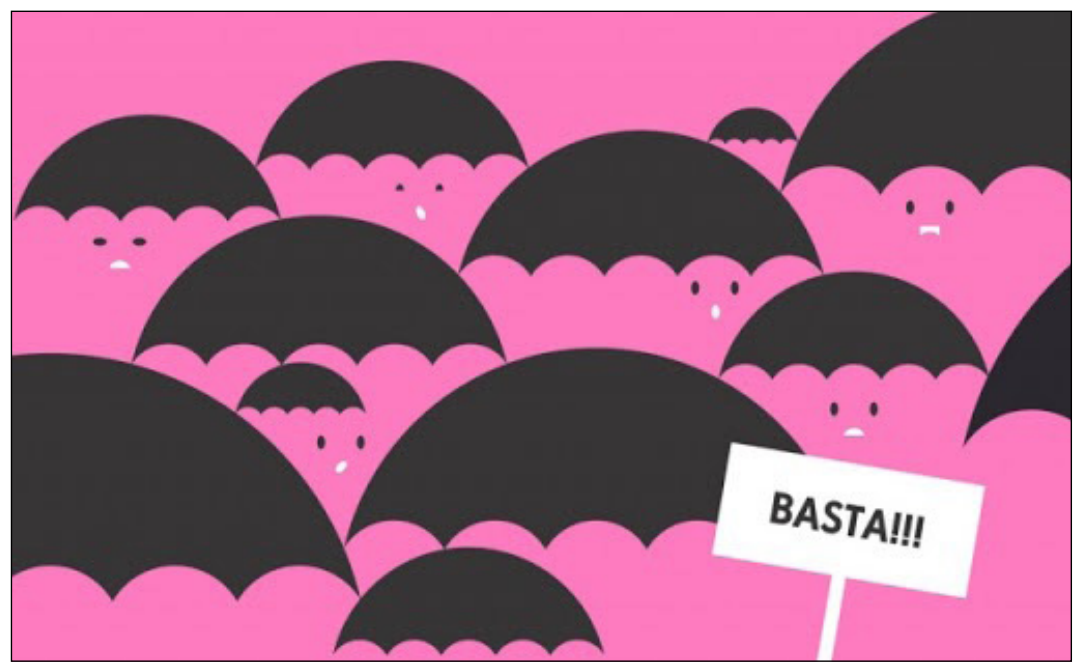

Il. 6. Rozkładówka z książki Egaliterra

Źródło: Wydawnictwo Wytwórnia, patrz też: Egaliterra / Ryms [online] [dostęp 20 grudnia 2020]. Dostępny w World Wide Web: http://www.ryms.pl/2019/ 11/16/egaliterra/

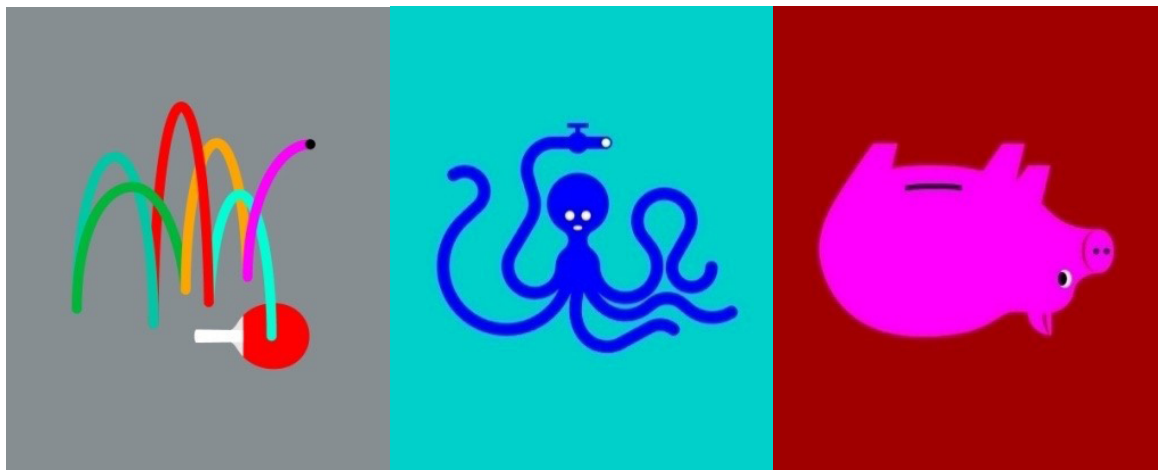

Il. 7-9. Ikony graficzne: „Energia”, „Wodny Świat”, „Kapitał” - internetowe zapowiedzi tematów spotkań edukacyjnych w CNK

Źródła: Edgar Bąk Studio/Realizacje [online] [dostęp 20 października 2020]. Dostępny w World Wide Web: https://edgarbak.info oraz Edukacja / Centrum Nauki Kopernik [online] [dostęp 20 października 2020]. Dostępny w World Wide Web: https://www.kopernik.org.pl/edukacja 


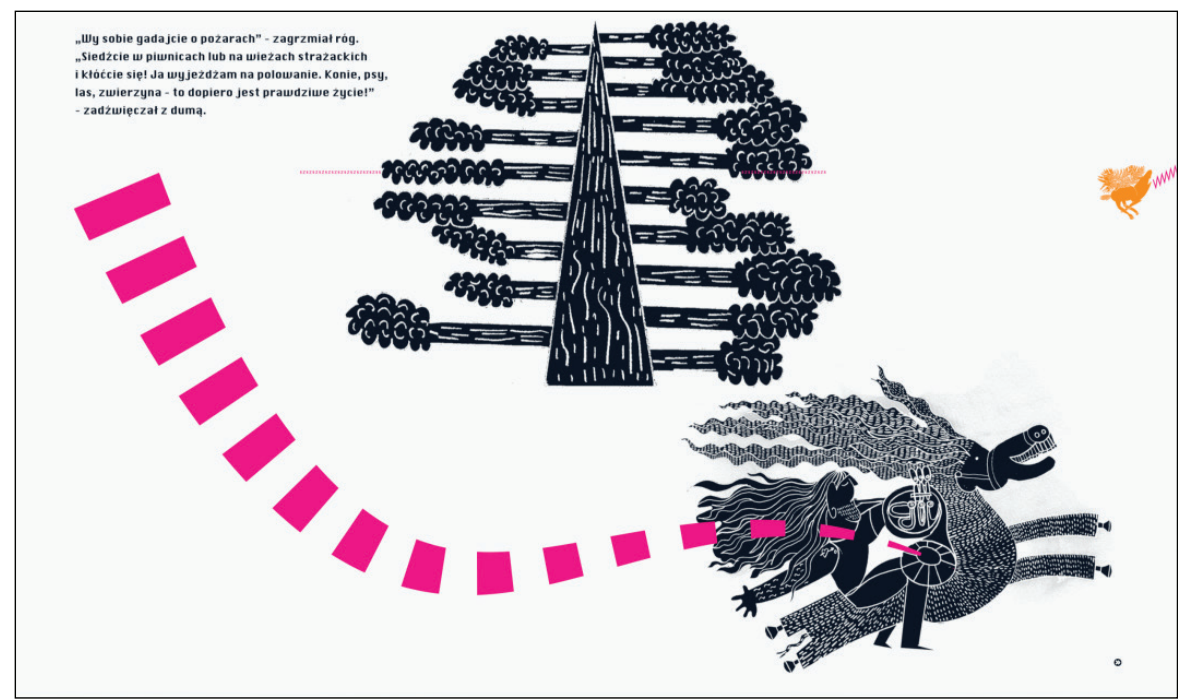

Il. 10. Rozkładówka z książki Wszystko gra!

Źródło: Wydawnictwo Wytwórnia

Analogiczną sytuację można zaobserwować u rozchwytywanej projektantki Marty Ignerskiej (il. 10-11). Kreślone przez nią postacie charakterystyczne, przerysowane, stylistycznie już rozpoznawalne może-ludzie/ półpotwory/ półmaszyny, zaludniają zarówno karty książek, jak i internetowe strony. Dmą w trąby i grają na skrzypcach, np. w wielokrotnie nagradzanej książce Wszystko gra, lądują na księżycu w Którędy do gwiazd?, lub kradną (!) polskie obrazy w czasie II wojny światowej, jak w animowanym projekcie internetowym Muzeum Utracone, realizowanym wespół przez MKiDN oraz SAR - Stowarzyszenie Komunikacji Marketingowej. W przypadku realizacji dla Muzeum Utraconego - zanimowane grafiki Ignerskiej nie pozostawiają złudzeń, co do inspiracji dla wizualnych strategii - jako żywo wyglądają (a nawet dźwięczą) jak gra komputerowa. Postaci są niczym rytm w brutalnej czasem poezji awangardowej, zmultiplikowane, ustawione w szeregu, groźne w swej ostrej konturowości i masie, a także w posłuszeństwie wobec krótkich poleceń i w swym natychmiastowym, bezrozumnym reagowaniu. Potencjalny obserwator śledzi losy „graczy” mierzących się z żołnierzami tłumu (sam graczem nie jest), zapewne z nadzieją, że rozgrywka dobrze skończy się 
dla pozytywnych postaci. Stwory Ignerskiej (i ich otoczenie), tworzone czy to na łamy książki obrazkowej czy dla animacji internetowej - są nie do odróżnienia. Ich marsz równie swobodnie może odbywać się na kartach kodeksu, jak i na stronach www.

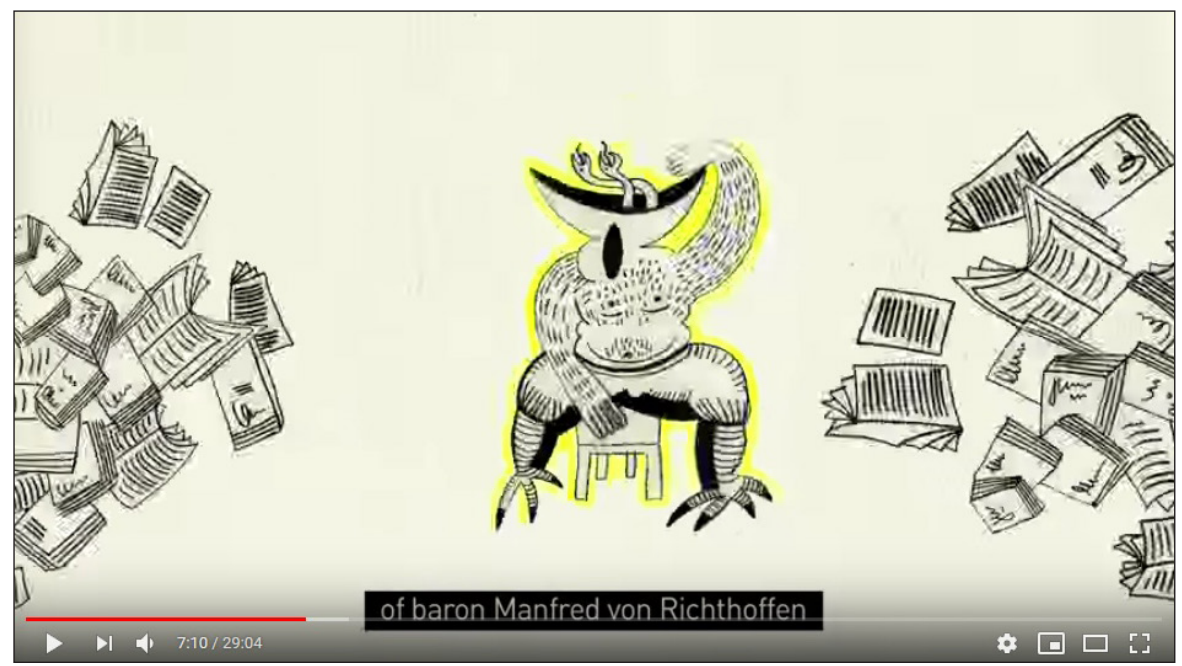

Il. 11. Kadr z komputerowej animacji dla internetowego projektu Muzeum Utracone 2014

Źródło: Marta Ignerska Art. - kadr filmu Muzeum Utracone 2014 [online] [dostęp 20 października 2020]. Dostępny w World Wide Web: https://muzeumutracone.pl/filmy/2014-filmy/.

Aleksandra i Daniel Mizielińscy (il. 12-14) tworzą od lat, z równym powodzeniem, zarówno książki, jak i gry on-line. Ich picturebooki - pełne kolorowych detali i wymagające wzrokowego skupienia na szczegółach, takie jak przetłumaczone na kilkanaście języków Mapy, a także Miasteczko Mamoko, Mam oko na liczby, Mam oko na litery, Let's Go Monsters, Podziemnik, Podwodnik, różnią się graficznie od internetowych realizacji tego duetu, takich jak Bubole, Pica Pici Ba Ba Dum, w zasadzie tylko „zagęszczeniem" elementów. Paradoksalnie internetowe realizacje są skromniejsze, czytelniejsze. Bohaterom internetowym nie towarzyszy takie nagromadzenie akcesoriów i detali z otoczenia, jak bohaterom książkowym. 


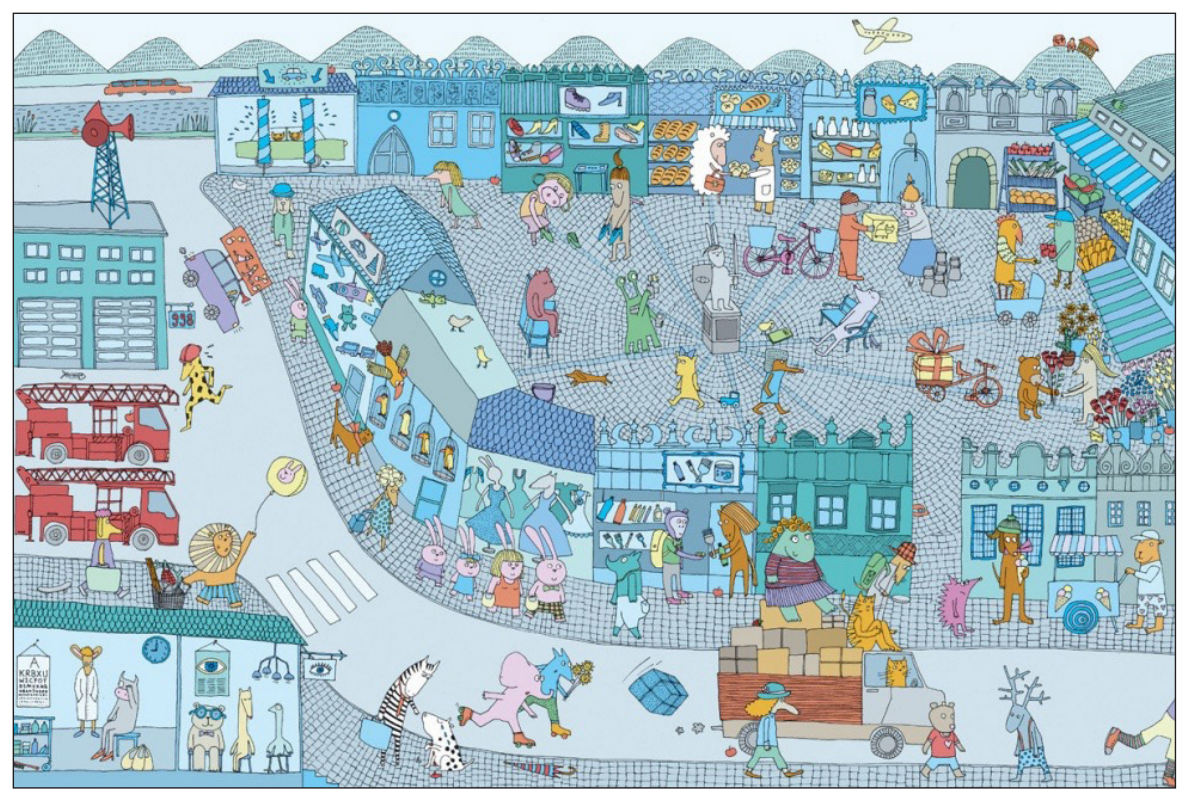

\section{Il. 12. Rozkładówka z książki Miasteczko Mamoko}

Źródło: Miasteczko Mamoko - Wydawnictwo Dwie Siostry [online] [dostęp 20 grudnia 2020]. Dostępny w World Wide Web: https://www.wydawnictwodwiesiostry.pl/katalog/prod-miasteczko_mamoko.html

Rekompensowane jest to dźwiękiem i ruchem. Poza tym jednak koncepty wizualne są tu niemal identyczne - ręcznie odmalowywane kontury postaci i liter, ciepłe, zgaszone kolory, w tle unikanie bieli na rzecz innych barw. Mizielińscy zachwycają swoimi grami nie tylko dzieci. Potwierdzają to nagrody wyróżniające internetowy design, przyznawane przez dorosłych - dorosłym. Mizielińscy zdobyli, np. za Buboli, prestiżową nagrodę FWA (FWA - serwis propagujący i nagradzający głosami 300 sędziów z 35 krajów wysmakowane graficzne projekty cyfrowych mediów). Co ciekawe, Mizielińscy tworząc w „formie papierowej”, kreują wizualne wrażenia charakterystyczne dla kompozycji grafiki komputerowej. W Podwodniku i Podziemniku czytelnik wodzi wzrokiem po ilustracji pokonując kolejne poziomy, spiętrzenia i piętra - jak w cyfrowej grze, tekst „wyskakuje” w niektórych punktach w specjalnej ramce, niczym okienko chatu zachęcające do rozmowy z moderatorem treści niedostępnych lub specjalnie 
ukrytych, a także dyktuje zadania. Formuła „hidden object”, praktykowana przez ilustratorów na potrzeby książki zabawki już w XIX w. ${ }^{22}$, a obecnie będąca podstawą wielu zadaniowych gier komputerowych, stosowana jest przez Mizielińskich jako strategia wizualna m.in. w Miasteczko Mamoko, Mam oko na liczby, Mam oko na litery. Powstają w ten sposób tzw. książki bez słów, wspierające spostrzegawczość i umiejętność samodzielnego, werbalnego tworzenia fabuły wynikającej wyłącznie z dowolnej interpretacji wybranych elementów ilustracji.

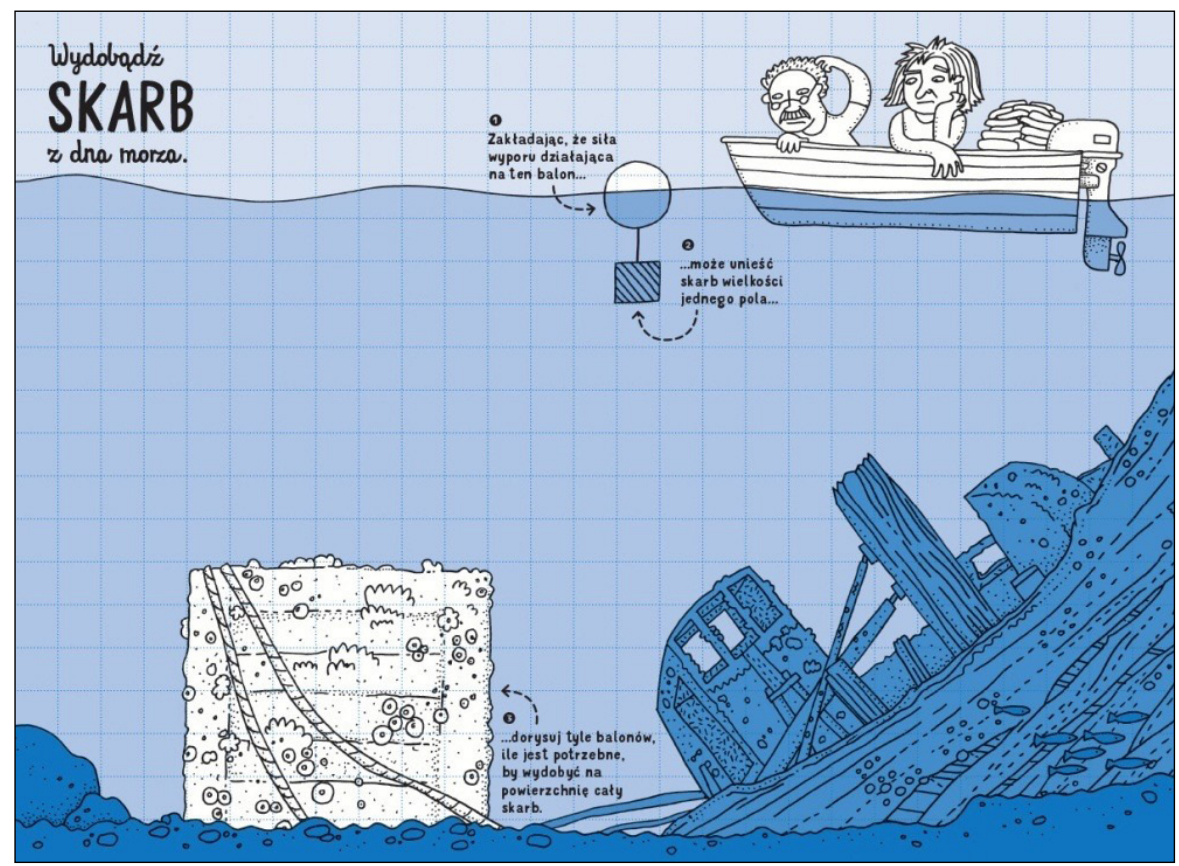

\section{Il. 13. Strona z książki Podwodnik}

Źródło: Podwodnik - Wydawnictwo Dwie Siostry [online] [dostęp 20 grudnia 2020]. Dostępny w World Wide Web: https://www.wydawnictwodwiesiostry. pl/katalog/prod-podwodnik.html

22 A. Maroń, Harmonijki, tarcze, klapki i żaluzje - książka zabawka na przestrzeni dziejów, „Bibliotheca Nostra. Sląski Kwartalnik Naukowy” 2011, nr 4, s. 62. 


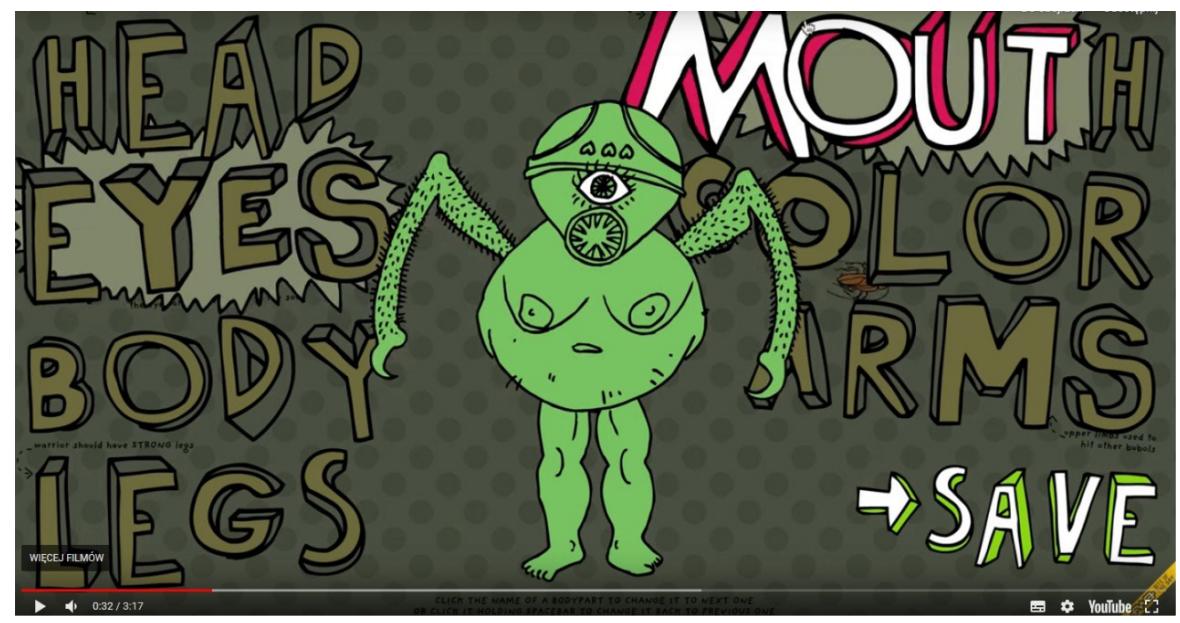

Il. 14. Kadr ze strony startowej kreatywnej gry internetowej Bubole

Źródło: Bubole - Aleksandra and Daniel Mizielińscy [online] [dostęp 20 października 2020]. Dostępny w World Wide Web: https://oladaniel.com/bubole

Ostatni z przytaczanych tu przykładów rodzimej twórczości dla dzieci (il. 15-16) - projekty Grażki Lange, kierowniczki Pracowni Typografii w warszawskiej Akademii Sztuk Pięknych, również wykazują podobieństwo wizualne, niezależnie od zastosowanego dla nich medium. Ulubiona przez graficzkę forma pudełka znalazła odzwierciedlenie w książce Warszawa, której okładka wyrażona jest poprzez wizerunek starego kartonu z drukarskimi czcionkami. Po rozwarciu kodeksu czytelnik jest zapraszany do „rozpakowywania” kolejnych paczek. Są tu torby, piórniki, koszyki, słoiki, puzderka. Ukazane są na ilustracji złożonej w pół - po jej odgięciu można zobaczyć na rozkładówce zawartość opakowań. Podobnie, przy wykorzystaniu strategii wizualnej, jaką jest sugerowanie kształtu opakowania, zaprojektowana jest przez G. Lange strona internetowa dla wydawnictwa Dwie Siostry. Jej pierwsza, główna odsłona wygląda jak „ikeowski” organizer podzielony przegrodami, w którym każdy z wydzielonych w małej przestrzeni fragmentów nie tylko co innego zawiera, ale ma też swoją kolejną, głębszą warstwę, możliwą do zbadania po „kliknięciu”. Takie rozwiązania są w Internecie de facto 
po prostu hipertekstem ${ }^{23}$. W hipertekście, w przeciwieństwie do drukowanych mediów, organizacja tekstu odbywa się na zasadzie leksji ${ }^{24}$, w których znajdują się odsyłacze do dalszych informacji. Przypomina to proste strategie wizualne, stosowane w twórczości dla dzieci już dekady temu. Rozpropagowane w XIX w. i popularne do dziś książki zabawki, z tzw. klapkami/okienkami, „działały i działają” na podobnej zasadzie. W pierwszej odsłonie ilustracji widoczne są informacje ogólne, a gdy czytelnik jest ciekaw szczegółów, możne podnieść „klapkę” i przeczytać/ /zobaczyć więcej.

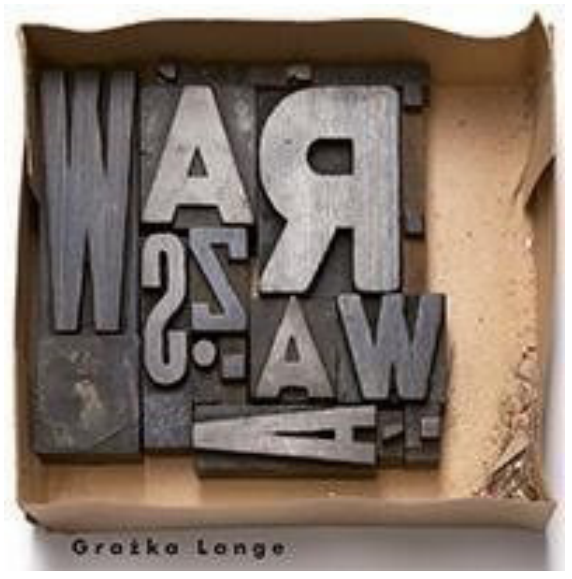

\section{Il. 15. Okładka pudełkowej książki Warszawa \\ Źródło: Wydawnictwo Tako [online] [dostęp 20grudnia 2020]. Dostępny w World Wide Web:http://tako.biz. $\mathrm{pl} / \mathrm{p}, 54$,warszawa.html}

${ }^{23}$ Hipertekst - organizacja danych w postaci niezależnych leksji (akapitów, fragmentów tekstu) połączonych hiperłączami (podkreślonymi lub wyróżnionymi kolorem odwołaniami do innego dokumentu). Hipertekst cechuje nielinearność i niestrukturalność układu tekstu, a więc nie ma z góry zdefiniowanej kolejności czytania fragmentów, a nawigacja między nimi zależy wyłącznie od użytkownika. To tekst, który rozgałęzia się lub działa na żądanie czytelnika. Termin ten stworzony został w 1965 r. przez Teda Nelsona na oznaczenie rodzaju hipermediów (powiązanych ze sobą poprzez łącze, z powodu wspólnego tematu lub tekstu, multimediów) o charakterze tekstowym. Przykłady hipertekstu obejmują oparty na hiperłączach hipertekst cząstkowy typu węzeł-link („discrete hypertext”) i oparty na poziomach szczegółowości tekst rozciągły („stretchtext”). Hipertekst - w szerszej perspektywie - to „ustrukturyzowana praca wiedzy”, za: M. Pisarski, Hipertekst - definicje, „Teksty. Literatura i nowe media” 2016, nr 1 (10) [online] [dostęp 15 czerwca 2020]. Dostępny w World Wide Web: http://techsty.art.pl/hipertekst/definicje.html.

${ }^{24}$ Leksja - spójna jednostka tekstu, która może obejmować ekran, akapit, zdanie itp., ponieważ poszczególne części utworu mogą być ze sobą połączone systemem „kli- 


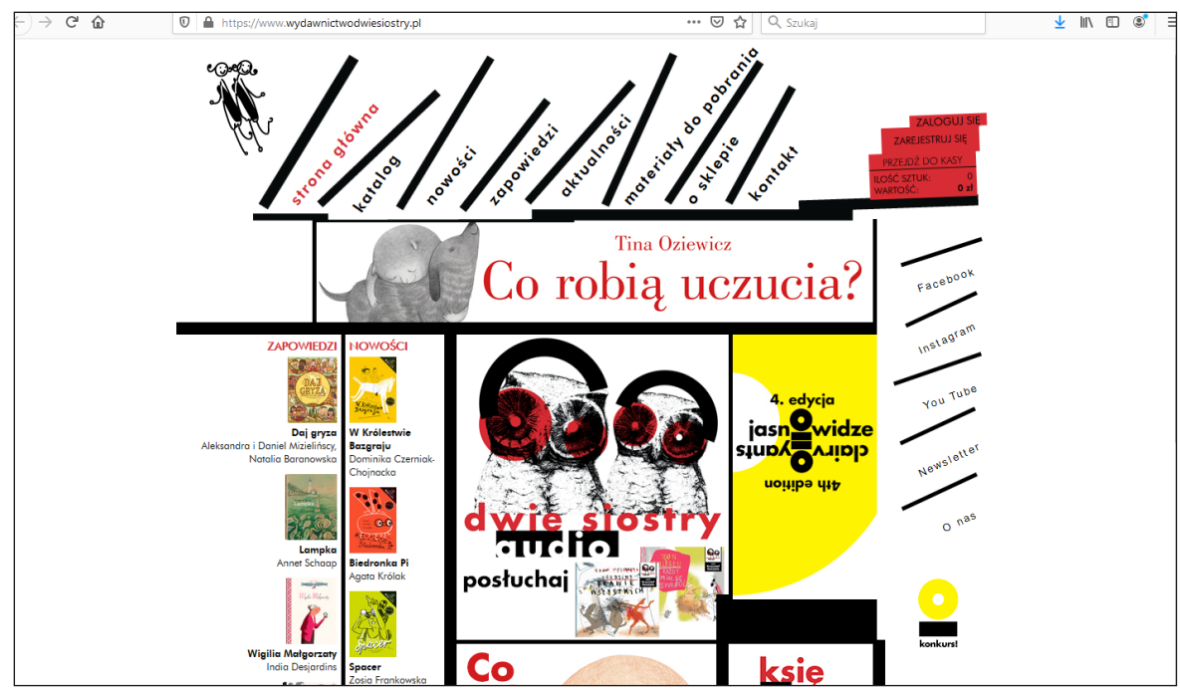

Il. 16. Strona tytułowa / pierwsza odsłona pudełkowo skomponowanego serwisu internetowego wydawnictwa Dwie Siostry

Źródło: Wydawnictwo Dwie Siostry [online] [dostęp 20grudnia 2020]. Dostępny w World Wide Web: http://www.wydawnictwodwiesiostry.pl

Twórczość wybranych tu polskich projektantów książek dla dzieci można też zestawiać z rozwiązaniami wizualnymi, stosowanymi przez innych internetowych twórców. Grozę i tajemniczość, uzyskiwaną przy pomocy ciemnych barw kontrastowanych z czerwienią, a także poprzez zastosowanie ostrych konturów czy ukazywanie fragmentów tylko niektórych obiektów i postaci (np. na ilustracji lub w kadrze widoczne są tylko oczy), zaobserwować można zarówno w książce Niebaśnie. Czerwony Kapturek Grażki Lange, jak i w grze komputerowej na podstawie tej baśni - The Path artystów Auriea'y Harvey, Michaëla Samyn i Laury Raines Smith. Inny przykład - wizualne zaproszenie do konsumpcji osiągane

kalnych” zdań lub haseł, czyli „linków” odsyłających do innych dokumentów/zbiorów treści. Za m.in.: M. Góralska, Książka elektroniczna - przeszłość i perspektywy, [w:] Oblicza kultury książki. Prace i studia z bibliologii i informacji naukowej, red. M. Komza i in., Wrocław 2005, s. 24. 
jest poprzez „rozsypanie” jedzenia (lub jego fragmentów) na stronie zarówno książkowej - Słodkie Abecadło Grażki Lange, jak i internetowej - patrz: witryna duńskiego producenta czekolady „Simply Chocolate” (https://simplychocolate.dk/). Duński producent zastosował ponadto na swojej stronie, w kontekście porządkowania tekstu, takie same strategie wizualne, jakie od lat stosowane są w plakacie - rozmieszczanie tekstu w centrum oraz w rogach prostokątnej formy komunikatu, gradacja informacji przy pomocy fontów - wielkości oraz kolorów liter, co wykazuje podobieństwo do omawianych wyżej projektów Edgara Bąka.

\section{Grywalność książek, baśniowość gier}

Wszystko jest nowe, czy wszystko już było?

- pytała w tytule swojego referatu, podczas konferencji dla projektantów internetowych GrafMag organizowanej w Toruniu w roku 2018, Emilia Bojańczyk z nagradzanego studia graficznego Podpunkt. I odpowiadała:

Ludzie dzielą się na takich, którzy myślą, że nic się nie zmienia i na takich, którzy uważają, że wszystko jest nowe. Ja należę do pierwszej grupy.

Nie jest twórczynią dla dzieci, ale wykazała podobieństwo strategii wizualnych w starych i nowych mediach w kontekście m.in. typografii, co jest dość uniwersalnym podejściem, ponieważ pismo jest wszędzie, również w projektach dla najmłodszych, i nie zostało jeszcze skutecznie/całkowicie wyparte przez obraz. Litera w Internecie jest elementem składowym obrazu, niesie ze sobą przekaz gradujący ważność informacji, bywa, że niesie też emocje. W twórczości dla dzieci jest to szczególnie widoczne, a u Jana Bajtlika jest wręcz podstawą przekazu (patrz Typogryzmoł). Internet od swojego zarania wzorował się na rozwiązaniach wizualnych stosowanych w papierowych mediach - stąd choćby nazwy, takie jak strona, menu. Ale dziś również twórcy książek, zwłaszcza dla dzieci, czerpią natchnienie z cyfrowych sposobów prezentacji - zrywają z linearnością tekstu, po stronach ilustrowanych bajek i opowieści, również tych „papierowych”, nawiguje się w różnorakich kierunkach, nierzadko 
w poszukiwaniu bohatera i innych detali, jak choćby w książkach typu hidden object, zupełnie w taki sam sposób, jak w popularnych grach komputerowych. Dziś książki są "grywalne” 25 nie tylko ze względu na stosowane strategie wizualne, ale również dlatego, że mamy do czynienia z nowymi formami książek - na rynek coraz powszechniej wchodzą pozycje multimedialne, hybrydowe, konwergencyjne ${ }^{26}$.

\section{Podsumowanie}

0 tym, że, jak stwierdziła cytowana wyżej projektantka dla mediów cyfrowych E. Bojańczyk, „wszystko już było”, również „to co jest” świadczy też twórczość nieżyjącej już pary artystów tworzących m.in. dla dzieci, Franciszki i Stefana Themersonów. Dla budowania przekazu wykorzystywali wszystkie możliwe media.

Rosnące obecnie zainteresowanie książką obrazkową (picturebook) spowodowało pojawienie się na współczesnym rynku wydawniczym wielu projektów artystycznych kontynuujących model Themersonowski

- pisze badaczka ich twórczości Beata Gromadzka ${ }^{27}$.

Franciszka i Stefan wyprzedzili swoją epokę, tworząc oryginalny i uniwersalny typ narracji właściwy dla świata interfejsów. Przekaz, z jakim mamy do czynienia w ich książkach dla dzieci, jest zintegrowaną werbalno-wizualną strukturą i należy traktować go jako jednolity, równoległy system znaczeń. Centralne miejsce znajduje w nim odbiorca prowokowany do wyborów, do poszukiwania porządków, do twórczej pracy umysłu. Themersonowie patronują nowoczesnej kul-

25 A. Mochocka, Między interaktywnościq a intermedialnościq̨. Ksiq̨żka jako przestrzeń gry, „Homo Ludens” 2009, nr 1, s.162.

${ }^{26}$ M. Zając, Od produktu totalnego do książki konwergencyjnej. Zwiq̨zki ksiq̨żki dla dzieci i młodzieży z innymi mediami, [w:] Współczesne oblicza komunikacji i informacji, red. E. Głowacka, M. Kowalska, P. Krysiński, Toruń 2014, s. 313-322.

27 B. Gromadzka, Themersonowie dzieciom, Poznań 2019, s. 12. 
turze wizualnej oddziałującej na odbiorcę wielokodowymi i wielotworzywowymi środkami.

Po przestudiowaniu realizacji graficznych polskich artystów tworzących dla dzieci zarówno w internecie, jak i na łamach papierowych książek kodeksowych, zwanych książkami obrazkowymi, lub z angielska - picturebookami, można wysnuć wniosek, że rodzaj medium, dla którego powstają, nie determinuje wizualnej strategii. Niezmiennie akcenty graficzne, ze względu na młodocianego odbiorcę, kładzione są na jaskrawość barw, prostotę formy, kreowanie fikcyjnych - miłych lub potwornych postaci, uwodzenie dynamiczną kreską i zwichrowaną literą. Strony i gry internetowe często przypominają książki, gdyż towarzyszy im tekst i opowieść oraz ta sama co w picturebookach ilustracja, strony książek obrazkowych coraz częściej wizualnie budowane są tak jak gry komputerowe i strony internetowe - są spiętrzone, wielopoziomowe, pojawiają się na nich labirynty, zagadki, ukryte informacje i zadania ${ }^{28}$. Czy z powodu doniesień z badań, dotyczących pokolenia iGen w kontekście jego obcowania z internetem (a przytaczanych na wstępie), taki stan rzeczy - wizualne upodabnianie książek obrazkowych do gier komputerowych, a w projektach internetowych budowanie przekazu na bazie obrazu kosztem słów, co niektóre strony WWW coraz bardziej upodabnia do picturebooków, powinien martwić? Na pewno nie dziwić. Jak pisał ludolog i literaturoznawca Jerzy Cieślikowski, pierwsza lektura w życiu dziecka zawsze jest zabawą ${ }^{29}$, ponadto przenikanie się mediów jest zgodne z mediamorfozą, czyli naturalną ewolucją mediów, którą wykazał w swych badaniach Roger Fidler ${ }^{30}$. Staranne dobieranie dziecku treści in-

${ }^{28}$ Prócz przykładów omówionych wyżej (np. zadania i zagadki pojawiają się w Typogryzmole Jana Bajtlika), takie strategie wizualne są widoczne w niemal wszystkich ostatnich książkach przywoływanych w niniejszym artykule autorów - Aleksandry i Daniela Mizielińskich (strony ich książek jako żywo przypominają dobrze zaprojektowane gry komputerowe), wśród nich tytuły, takie jak: Pod ziemiq, pod wodq, Warszawa 2015, Mapownik, czyli praktyczny kurs mazania po mapach, Warszawa 2016, Którędy do Yellowstone? Dzika podróż po parkach narodowych, Warszawa 2020, Daj gryza. Smakowite historie o jedzeniu, Warszawa 2020.

${ }^{29}$ J. Cieślikowski, Zabawa jako struktura pewnych tekstów literackich dla dzieci, [w:] J. Cieślikowski, Literatura osobna, Warszawa 1985, s. 65.

${ }^{30}$ W Polsce piszą o tej koncepcji m.in.: T. Goban-Klas, Społeczeństwo medialne, Warszawa 2005; M. Szpunar, Mediamorfoza a rozwój i funkcjonowanie internetu, [w:] 
ternetowych, gier on-line czy elektronicznych bajek, zarówno pod kątem estetyki wizualnej, jak i zawartości merytorycznej dostosowanej stopniem trudności do jego wieku i percepcyjnych możliwości, przy jednoczesnym wykazywaniu i podkreślaniu podobieństw, choćby wizualnych, pomiędzy „starymi” a „nowymi” mediami, może być, paradoksalnie, czynnikiem promującym kulturę czytelniczą i wprowadzającym dziecko do rodziny czytelniczej. Dzięki takim zabiegom - poprzez wskazywanie podobieństw a nie różnic, nie będzie ono, być może, traktowało w przyszłości książki jak archetypicznego gadżetu niemającego nic wspólnego z jego współczesnością. Jak zauważa Anita Has-Tokarz:

O książce dla dzieci i młodzieży nie sposób dziś mówić bez uwzględniania kontekstu medialnego - teksty literackie dla młodych czytelników funkcjonują przecież w środowisku kultury zmediatyzowanej ${ }^{31}$, w otoczeniu różnorodnych przekazów. Wchodzą w relacje z nimi, tworząc siatki wielowymiarowych powiązań, stanowiących odrębne, złożone, wielomedialne systemy ${ }^{32}$.

\section{Bibliografia}

Bąk Agnieszka, Korzystanie z urzq̨dzeń mobilnych przez małe dzieci w Polsce. Wyniki badania ilościowego. Raport Fundacji Dzieci Niczyje, Warszawa 2015. Bożek Agata, Kamińska-Mazur Lena, Książka hybrydowa - kod QR sposobem na koegzystencję książki drukowanej z e-bookiem. „Biuletyn EBIB” [online] 2012, nr 7 (134) [dostęp 15 października 2020]. Dostępny w World Wide Web: http://ebibojs.pl/index.php/ebib/article/view/513

Cackowska Małgorzata, Co ma książka obrazkowa do interaktywnej aplikacji książkowej?, „Ryms” 2013, nr 20, s. 2-4.

Imperializm kulturowy internetu, red. M. Szpunar, Kraków 2017, s. 124-133 i A. Ziemski, Nowa architektura mediów, „Naukowy Przegląd Dziennikarski/Journalism Research Review Quarterly" 2018, nr 3, s. 101-117.

${ }^{31} 0$ rozróżnieniu pomiędzy przestrzenią (kulturą) zmediatyzowaną a przestrzenią medialną pisze B. Kita, Między przestrzeniami. O kulturze nowych mediów, Kraków 2003.

32 A. Has-Tokarz, „Monster High” jako transmedialna opowieść - od książki do monsterhighmanii, „Acta Universitatis Wratislaviensis”, nr 3577 „Literatura i Kultura Popularna" XIX, 2013, s. 29. 
Cackowska Małgorzata, Książka obrazkowa, [w:] Encyklopedia dzieciństwa, red. Danuta Waloszek [online] Zielona Góra 2015. [dostęp 1 września 2020]. Dostępny w World Wide Web: http://encyklopediadziecinstwa.pl/index. php/Ksi\%C4\%85\%C5\%BCka_obrazkowa

Cieślikowski Jerzy, Zabawa jako struktura pewnych tekstów literackich dla dzieci, [w:] Cieślikowski Jerzy, Literatura osobna, Warszawa 1985, s. 64-71.

Gierczak-Cywińska Agnieszka, Ogranicz ekrany, zadbaj o mózg swojego dziecka, [w:] Polityka.pl [online] [dostęp 15 października 2020]. Dostępny w World Wide Web: http://ogranicz-ekrany-zadbaj-o-mozg-swojego-dziecka.read Goban-Klas Tomasz, Społeczeństwo medialne, Warszawa 2005. Gromadzka Beata, Themersonowie dzieciom, Poznań 2019.

Góralska Małgorzata, Książka elektroniczna - przeszłość i perspektywy, [w:] Oblicza kultury ksiqż́ki. Prace i studia z bibliologii i informacji naukowej, red. Małgorzata Komza i in., Wrocław 2005, s. 11-28.

Góralska Małgorzata, Ksiq̨żki, nowe media i ich czasoprzestrzenie, Warszawa 2009. Has-Tokarz Anita, „Monster High” jako transmedialna opowieść - od ksiqż́ki do monsterhighmanii „Acta Universitatis Wratislaviensis”, nr 3577 „Literatura i Kultura Popularna" XIX, 2013, s. 29-38.

Jamróz-Stolarska Elżbieta, Biernacka-Licznar Katarzyna, Paprocka Natalia, Lilipucia rewolucja: awangardowe wydawnictwa dla dzieci i młodzieży w Polsce w latach 2000-2015. Produkcja wydawnicza, bibliografia, Warszawa 2018. Janusz-Lorkowska Monika, iGen jako użytkownik informacji w kontekście kategorii generacji - próba ujęcia na podstawie ksiq̨żki Jean M. Twenge „iGen”, „Toruńskie Studia Bibliologiczne” 2019, nr 2 (23), s. 139-158.

Jegier Aneta, Media w wychowaniu dzieci - korzyści i zagrożenia, [w:] Wychowanie i wspieranie rozwoju małych dzieci $w$ domu, żłobku i przedszkolu, red. Anna Mikler-Chwastek, Warszawa 2017, s. 182-195.

Kita B., Między przestrzeniami. O kulturze nowych mediów, Kraków 2003.

Kotuła Sebastian Dawid, Komunikacja bibliologiczna wobec World Wide Web, Warszawa 2012.

Kruszyńska Elżbieta, Książka obrazkowa i jej rola w rozwoju dzieci - wprowadzenie w problematykę, „Warmińsko-Mazurski Kwartalnik Naukowy. Nauki Społeczne", Olsztyn 2012, s. 183-190.

Maroń Agnieszka, Harmonijki, tarcze, klapki i żaluzje - książka zabawka na przestrzeni dziejów, „Bibliotheca Nostra. Śląski Kwartalnik Naukowy” 2011, nr 4 (26), s. 61-72. 
Matras-Mastalerz Wanda, Potencjał edukacyjny, socjalizacyjny, wychowawczy i terapeutyczny książki dziecięcej, [w:] Książki w życiu najmłodszych, red. Mariola Antczak, Agata Walczak-Niewiadomska, Łódź 2015, s. 105-120.

Mochocka A., Między interaktywnościq a intermedialnościq̨. Książka jako przestrzeń gry, „Homo Ludens” 2009, nr 1, s. 155-176.

Przyszłość książki, red. Geoffrey Nunberg, Warszawa 2013.

Papuzińska Joanna, Wpływ świata mediów na kształt książki dziecięcej i style jej odbioru, [w:] Książka dziecięca 1990-2005. Konteksty kultury popularnej i literatury wysokiej, pod red. nauk. Grzegorza Leszczyńskiego, Danuty Świerczyńskiej-Jelonek, Michała Zająca, Warszawa 2006, s. 13-31.

Salisbury Martin, Styles Morgan, Children's Picturebooks. The Art of Visual Storytelling, Londyn 2012.

Słońska Irena, Psychologiczne problemy ilustracji dla dzieci, Warszawa 1977.

Szpunar Magdalena, Mediamorfoza a rozwój i funkcjonowanie internetu, [w:] Imperializm kulturowy internetu, red. Magdalena Szpunar, Kraków 2017, s. $124-133$

Teodorczyk Anna, Pomiędzy sztuką a edukacją. Ilustracja w książkach dla dzieci i młodzieży (pod przewodnictwem prof. M. Adamczyka) [dla:] STGU (Stowarzyszenie Twórców Grafiki Użytkowej) [online] [dostęp 2 września 2020]. Dostępny w World Wide Web: https://www.stgu.pl/stgu_files/Files/ Anna_Teodorczyk_Pomi\%C4\%99dzy_sztuk\%C4\%85_a_edukacj\%C4\%85_ poprawiona.pdf

Twenge Jean M., iGen. Dlaczego dzieciaki dorastające w sieci sq mniej zbuntowane, bardziej tolerancyjne, mniej szczęśliwe - $i$ zupełnie nieprzygotowane do dorosłości. I co to oznacza dla nas wszystkich, Sopot 2019.

Zając Michał, Od produktu totalnego do ksiq̨żki konwergencyjnej. Zwiqzzki ksiq̨żki dla dzieci i młodzieży z innymi mediami, [w:] Współczesne oblicza komunikacji i informacji, red. Ewa Głowacka, Małgorzata Kowalska, Przemysław Krysiński, Toruń 2014, s. 313-322.

\section{Wykaz ksiq̨żek oraz projektów internetowych analizowanych lub porównywanych w tekście}

\section{Ksiq̨żki}

Bajtlik Jan - Auto (2013), Typogryzmoł (2014), Nić Ariadny (2018) 
Bąk Edgar - Mam prawo i nie zawaham się go użyć! (2014), Kto Ty Jesteś? (2015), Egaliterra (2017)

Ignerska Marta - Wszystko gra (2012), Którędy do gwiazd? (2014)

Lange Grażka - Niebaśnie. Czerwony kapturek (2010), Słodkie abecadło (2014),

Warszawa (2015)

Mizielińscy Aleksandra i Daniel - Miasteczko Mamoko (2010), Mam oko na liczby (2016), Mam oko na litery (2016), Podwodnik (2016), Podziemnik (2016),

\section{Projekty internetowe}

Bajtlik Jan - Doodle dla przeglądarki Google w dniu 11 listopada 2018 r.: https:// www.wprost.pl/zycie/10167578/google-swietuje-niepodleglosc-polskiwyjatkowa-grafika-na-stronie-glownej.html, także: http://jan-bajtlik. squarespace.com/google-doodle;

Bąk Edgar - 50 powodów, dla których na naukę nigdy nie jest za późno, Centrum Nauki Kopernik: https://www.kopernik.org.pl/edukacja

Ignerska Marta - animowane filmy rysunkowe dla projektu Muzeum Utracone: http://archiwum.nina.gov.pl/katalog?Filter.PersonCodenames=martaignerska

Lange Grażka - strona tytułowa/ pierwsza/główna odsłona pudełkowo skomponowanego serwisu internetowego wydawnictwa Dwie Siostry: https:// www.wydawnictwodwiesiostry.pl

Mizielińscy Aleksandra i Daniel - gra rozrywkowa Bubole: http://www.bubole.pl oraz https://oladaniel.com/; gra edukacyjna Ba Ba Dum: https://babadum. com/; kolekcja gier komputerowych inspirowanych pierwszymi tego typu grami z lat 80. Pica Pic: http://pica-pic.com/

Harvey Auriea, Samyn Michaël i Raines Smith Laura komputerowa gra wideo The Path: https://www.gry-online.pl/gry/the-path/z9206a

\section{Picturebooks and internet projects - similarities in visual strategies used by Polish artists for children}

ABSTRACT: The article, based on selected examples, shows the parallelism of graphic designs created in Poland, addressed to the youngest audience and published in both paper codex books and digital internet projects. The visual „art of 
the Internet" is inspired by a traditional book, and the latest picturebooks are inspired by the Internet and computer games. The visual similarity of children's pictorial stories and educational messages in old (paper) and new (electronic) media, often made by the same authors, indicate mediamorphosis of content carriers and allow for smooth transitions between them, while dispelling some of the concerns related to the child's participation in digital culture.

KEYWORDS: visual strategies, creativity for children, picturebook, new media, internet projects, graphics for children. 